\title{
Serum levels of growth hormone-binding protein and insulin-like growth factor $I$ in children and adolescents with Type 1 (insulin-dependent) diabetes mellitus
}

\author{
G. Massa $^{1}$, L. Dooms ${ }^{1}$, R. Bouillon ${ }^{2}$ and M. Vanderschueren-Lodeweyckx ${ }^{1}$ \\ ${ }^{1}$ Department of Paediatrics and \\ ${ }^{2}$ Laboratory for Experimental Medicine and Endocrinology, University of Leuven, Leuven, Belgium
}

\begin{abstract}
Summary. Serum levels of insulin-like growth factor I are reduced in patients with Type 1 (insulin-dependent) diabetes mellitus. To evaluate the role of the hepatic growth hormone receptor in the decreased serum concentrations of insulinlike growth factor I, serum levels of the high affinity growth hormone-binding protein, which is qualitatively and quantitatively related to the hepatic growth hormone receptor, and of insulin-like growth factor I were measured in 70 children and adolescents with Type 1 diabetes and 105 healthy control children. Analysis of variance revealed a significant negative effect of Type 1 diabetes on serum levels of the growth hormone-binding protein and of insulin-like growth factor I. In the diabetic patients, serum levels of the growth hormonebinding protein were positively related to body mass index and to insulin dose per $\mathrm{kg}$ body weight, and were not influenced by pubertal stage, gender, or plasma levels of
\end{abstract}

haemoglobin $\mathrm{A}_{1 \mathrm{c}}$. Serum levels of insulin-like growth factor I increased during early puberty reaching peak levels at midpuberty and decreasing thereafter. No relationship was found between serum levels of growth hormone-binding protein and of insulin-like growth factor I. Our data suggest that decreased liver somatogenic receptor levels, as reflected by the concentrations of circulating growth hormone-binding protein, play a minor role in the suppressed concentrations of circulating insulin-like growth factor I. Post-growth hormone receptor defects or changes in the insulin-like growth factor binding proteins probably contribute more to the lower serum levels of insulin-like growth factor I.

Key words: Body mass index, growth hormone, growth hormone-binding protein, growth hormone receptor, insulinlike growth factor, puberty.
Disturbances of the growth hormone $(\mathrm{GH})$-insulin-like growth factor (IGF)-I axis are common in patients with Type 1 (insulin-dependent) diabetes mellitus [1-6]. Despite elevated serum GH concentrations [1-3] circulating IGF-I levels are reduced [4-6]. Animal studies suggest that the low serum IGF-I levels are due to a diminished hepatic IGF-I production caused by a decreased number of cellular $\mathrm{GH}$ receptors $[7,8]$ and by post-receptor defects $[9,10]$.

Recently, a circulating binding protein (BP) with high affinity for $\mathrm{GH}$ has been detected in animal $[11,12]$ and human serum $[13,14]$. It has been shown that this GH-BP corresponds to the extracellular part of the cellular GH receptor [15] and it has been suggested that the serum levels of this $\mathrm{GH}-\mathrm{BP}$ reflect the hepatic $\mathrm{GH}$ receptor status [12, $16]$.

In the present study we measured circulating GH-BP and IGF-I levels in 70 children and adolescents with Type 1 diabetes and evaluated the influence of pubertal development, gender, body mass index, insulin therapy and blood levels of haemoglobin $\mathrm{A}_{1 \mathrm{c}}$ on serum concentra- tions of GH-BP and IGF-I. To evaluate whether changes in cellular GH receptor levels, as reflected by the concentrations of circulating GH-BP, might lead to changes in serum IGF-I concentrations we also studied the relationship between serum levels of GH-BP and IGF-I.

\section{Subjects and methods}

Study population. Seventy diabetic children and adolescents ( 28 girls and 42 boys), aged 8 to 19 years, were studied. They all had Type 1 diabetes and had been treated with short- and medium-acting insulin (twice daily) for at least 1.year. The mean \pm SEM duration of diabetes was $6.4 \pm 0.5$ years. None of the patients had any diabetic complications or was currently taking other medication.

Control population. The data obtained in the diabetic patients were compared with those obtained in 105 age- and pubertal stagematched healthy subjects ( 59 girls and 46 boys).

Blood samples. In the diabetic patients blood samples were taken during a routine medical visit to the out-patient clinic. In the control 
Table 1: Mean \pm SEM data of diabetic patients (D) compared to non-diabetic controls subjects (C)

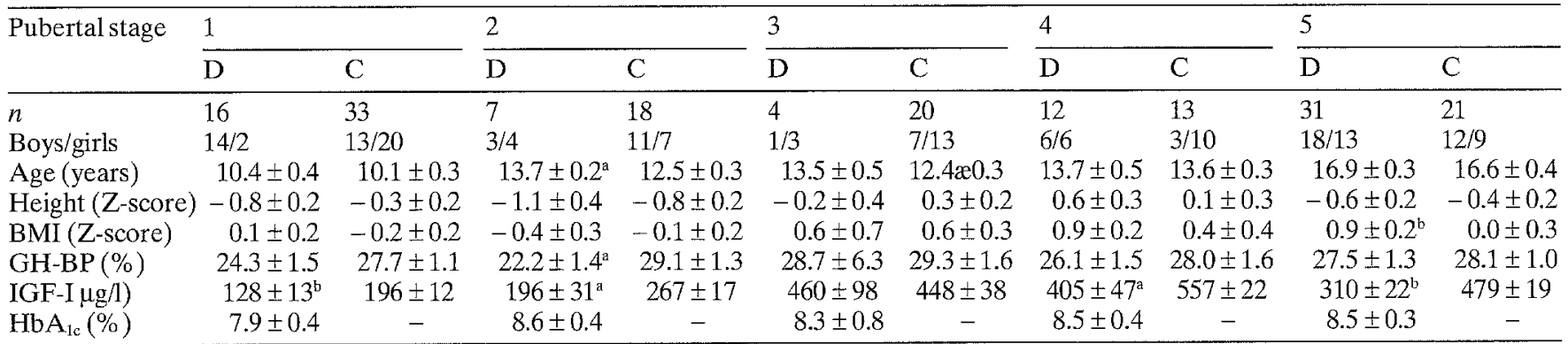

${ }^{\mathrm{a}} p<0.05 ;{ }^{\mathrm{b}} p<0.005$ compared to control group of same pubertal stage.

GH-BP, growth hormone-binding protein; IGF-I, insulin-like growth factor I

subjects blood samples were obtained during a routine school medical examination after informed consent was obtained from the parents. Blood was collected into glass tubes; after clotting at $4^{\circ} \mathrm{C}$, the blood was centrifuged and the serum kept frozen at $-20^{\circ} \mathrm{C}$ until assayed.

Auxological methods. Pubertal development was evaluated according to the five stages of genital development of Tanner [17]. Height is expressed as Z-score for chronological age, using the standards described by Roede and Van Wieringen [18]. Body mass index (BMI) is expressed as Z-score, according to the method and the references of Rolland-Cachera et al. [19].

Serum binding of growth hormone. Serum levels of GH-BP were determined by high pressure liquid chromatography (HPLC) gel filtration method as previously described [20]. In brief, $100 \mu \mathrm{l}$ serum were incubated overnight at $4^{\circ} \mathrm{C}$ with $40,000 \mathrm{cpm}^{125} \mathrm{I}$-hGH (NovoNordisk, Gentofte, Denmark) in the absence or presence of $1 \mu \mathrm{g}$ of unlabelled biosynthetic hGH (Novo-Nordisk) in a total volume of $200 \mu \mathrm{l}$. In order to separate bound from free ${ }^{125} \mathrm{I}-\mathrm{hGH}$ the incubation mixture was placed onto an HPLC Protein Pak 300sw $(0.05 \%$ sodium azide in water) column (Waters, Milford, Mass., USA) eluted at a flow rate of $0.5 \mathrm{ml} / \mathrm{min}$. The levels of the $\mathrm{GH}-\mathrm{BP}$ were calculated by dividing the radioactivity found in this peak by the sum of the radioactivities found in the peak of bound and free ${ }^{125} \mathrm{I}-\mathrm{hGH}$. The results are expressed as a percentage of specific binding of ${ }^{125} \mathrm{I}-\mathrm{hGH}$, calculated as the difference between total (no excess of unlabelled $\mathrm{hGH}$ ) and non-specific binding ( $1 \mu \mathrm{g}$ unlabelled hGH). When high levels $(>7 \mu \mathrm{g} / \mathrm{l})$ of circulating $\mathrm{hGH}$, measured by an immunoradiometric assay (hGH-IRMA; Medgenix, Fleurus, Belgium), were present, the percentage ${ }^{125} \mathrm{I}-\mathrm{hGH}$ binding was corrected for occupancy by endogenous GH on the base of a displacement curve obtained by adding increasing concentrations of unlabelled hGH to a reference serum with less than $1 \mu \mathrm{g} / \mathrm{l}$ endogenous hGH. The percentage of ${ }^{125} \mathrm{I}-\mathrm{hGH}$ bound was divided by the fraction bound in the reference serum at the hGH concentration found in the unknown sample. The inter-assay coefficient of variation was $8 \%$.

Radioimmunoassay of IGF-I. Serum levels of IGF-I were determined after acid-ethanol extraction by radioimmunoassay using a polyclonal guinea pig antiserum and recombinant human IGF-I as internal standard and labelled hormone [21]. Acid-ethanol extraction removed more than $95 \%$ of the IGF binding proteins in serum samples. Results are expressed in $\mu \mathrm{g} / 1$. The inter- and intra-assay coefficients of variation were $7.7 \%$ and $7.4 \%$, respectively.

Measurement of $H b A_{1 \mathrm{C}}$. Glycosylated haemoglobin levels were determined by HPLC on blood collected in EDTA-containing tubes. Normal levels are between 3.6 and $6.4 \%$.

\section{Statistical analysis}

Results are expressed as mean $\pm \operatorname{SEM}(n)$. The effect of Type 1 diabetes and pubertal stage on height (Z-score), BMI (Z-score), and on serum levels of GH-BP and IGF-I was measured by two-way analysis of variance (ANOVA) or by two-way analysis of covariance (ANCOVA) to adjust for the effect of BMI, as indicated. Differences between groups were evaluated by the unpaired Student's $t$-test. The relationship between parameters was evaluated by uni- or multivariate linear regression analysis, as indicated. In the multivariate linear regression analysis only those parameters with a $p<0.05$ were included in the final regression model. Comparisons between two regression equations were performed by $t$-test for parallelism and for common intercept. Levels of significance are expressed by two-tailed $p$ values. All statistics were performed with the True Epistat Program [22].

\section{Results}

\section{Effect of Type 1 diabetes and pubertal stage on height, $B M I$ and on serum levels of $G H-B P$ and $I G F-I$}

Table 1 shows relevant data and results of the diabetic patients compared to the non-diabetic control subjects. No differences in height were found between diabetic and control subjects. BMI increased during puberty in the diabetic patients, and was during late puberty higher than in the control subjects. Two-way ANOVA revealed no effect of Type 1 diabetes on height. Pubertal stage, in contrast, significantly influenced height $(F=5.9 ; p<0.005)$. BMI was significantly influenced by Type 1 diabetes $(F=9.3 ; p<0.005)$ and pubertal stage $(F=3.7 ; p<0.01)$.

Serum levels of GH-BP did not change significantly during puberty, either in the diabetic or in the control subjects (Fig. 1, upper panel). The serum levels were in general lower in the diabetic subjects. Two-way ANOVA revealed a significant effect of Type 1 diabetes $(F=5.3$; $p<0.05$ ), but no effect of pubertal stage on serum levels of GH-BP.

Serum concentrations of IGF-I increased during early puberty in diabetic and control subjects reaching peak levels at mid-puberty and decreasing thereafter (Fig. 1, lower panel). Two-way ANOVA showed significant effects of Type 1 diabetes $(F=20.2 ; p<0.0001)$ and pubertal stage $(F=54.4 ; \mathrm{p}<0.0001)$ on serum levels of IGF-I. There was also a significant interaction between both variables $(F=3.6 ; p<0.01)$. Except for pubertal stage 3, 

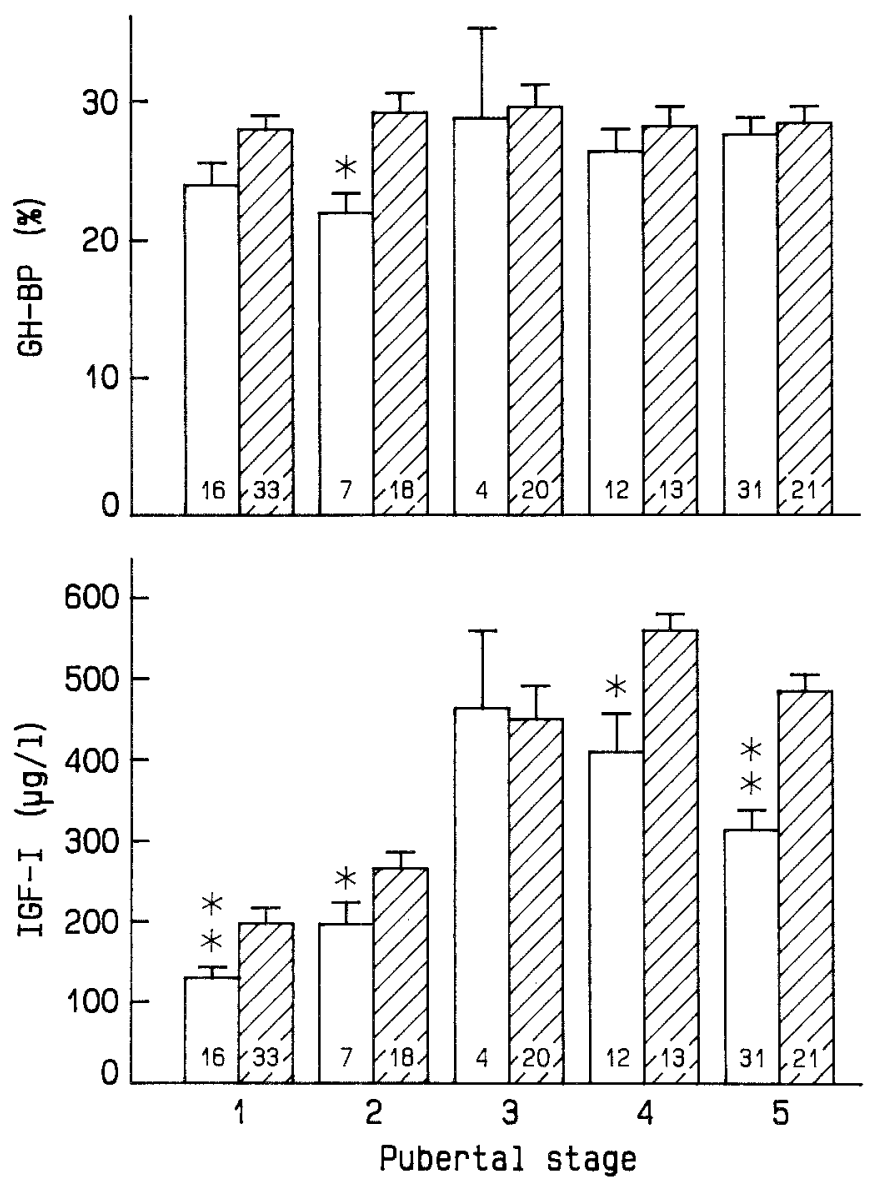

Fig. 1. Serum levels (mean \pm SEM) of growth hormone-binding protein (GH-BP, upper panel) and of insulin-like growth factor I (IGF-I, lower panel) in diabetic patients $(\square)$ and healthy control subjects (छ). The numbers in the bars represent the number of subjects in each pubertal stage group $(* p<0.05 ; * * p<0.005)$

where the number of diabetic patients is too small for a valid comparison, the serum levels of IGF-I were lower in the diabetic than in the control subjects, especially during late puberty.

\section{Regression analysis}

In the diabetic subjects the relationship between gender, age, pubertal stage, BMI, insulin dose per $\mathrm{kg}$ body weight and plasma $\mathrm{HbA}_{1 \mathrm{c}}$ (independent variables) and serum levels of GH-BP and IGF-I (dependent variables) was evaluated by multivariate linear regression analysis. Independent variables with $p>0.05$ were removed from the final regression model. Only BMI $(t=3.13 ; p<0.005)$ and insulin dose per $\mathrm{kg}$ body weight $(t=2.61 ; p<0.02)$ were included in the GH-BP regression equation $\left(R^{2}=0.23\right.$; $F=10.0 ; p<0.0005)$. In contrast, pubertal stage $(t=5.56$; $p<0.0005)$ and age $(t=-3.31 ; p<0.002)$ were included in the IGF-I regression model $\left(R^{2}=0.34 ; F=17.4\right.$; $p<0.0001)$. No relationship was found between gender or plasma levels of $\mathrm{HbA}_{1 \mathrm{c}}$ and serum levels of GH-BP or IGF-I.

Figure 2 shows the relationship between BMI and serum levels of GH-BP (upper panel) and IGF-I (lower panel) in the diabetic and control subjects as evaluated by

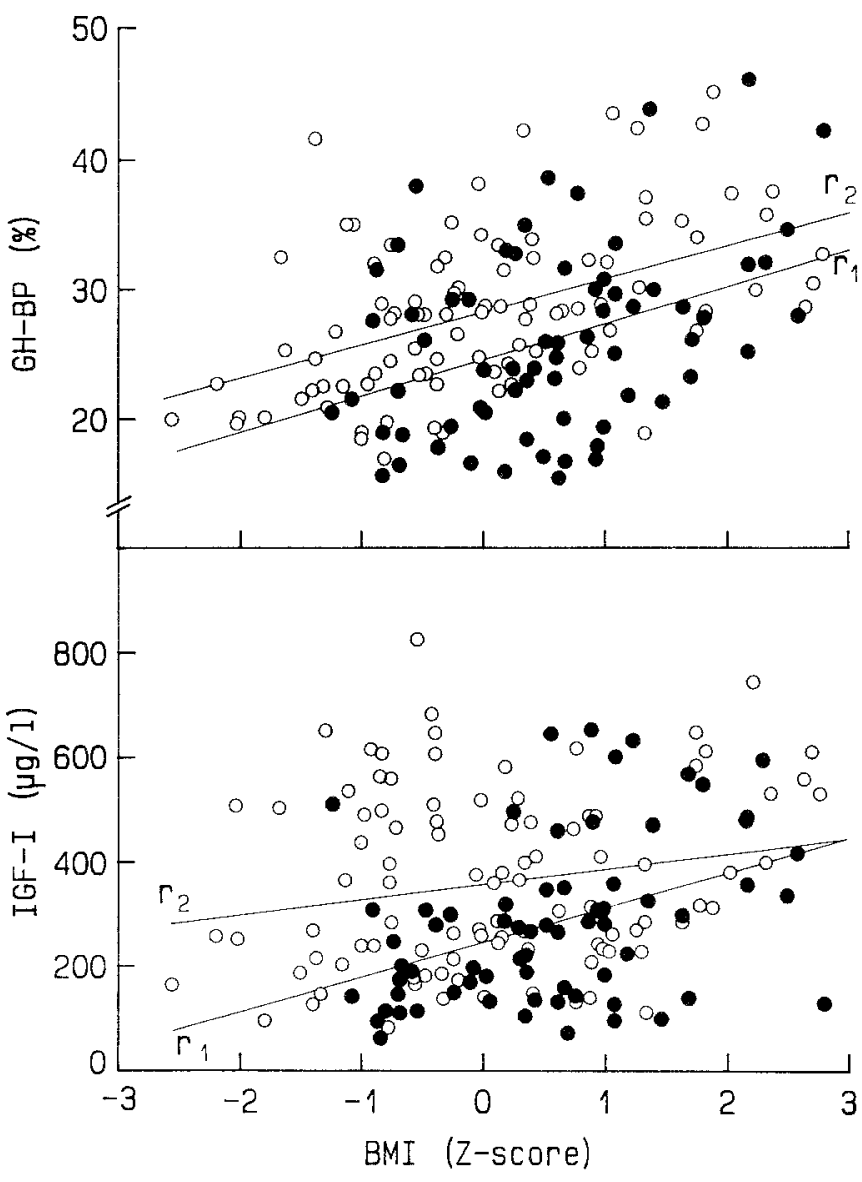

Fig. 2. Relationship between BMI (Z-score) and serum levels of growth hormone-binding protein (GH-BP, upper panel) and of insulin-like growth factor I (IGF-I, lower panel). Diabetic patients $(\bullet)$ $\left(r_{1}\right) ;$ control subjects $(o)\left(r_{2}\right)$

univariate linear regression analysis. Serum levels of GH$\mathrm{BP}$ were positively related to $\mathrm{BMI}$ in the diabetic patients $(r=0.38 ; p=0.001)$ and control subjects $(r=0.48$; $p<0.0001)$. Moreover, the slope of the regression lines was similar in both groups (diabetic patients: 2.80 ; control subjects: 2.53 ), with a significant difference of about $5 \%$ binding in elevation of the regression line $(t=16.9$; $p<0.0001)$. When two-way ANCOVA was performed evaluating the effect of Type 1 diabetes or pubertal stage on serum levels of GH-BP taking BMI as covariate, the effect of Type 1 diabetes on serum levels of GH-BP became highly significant $(F=14.7 ; p<0.0005)$. No effect of pubertal stage on GH-BP levels could be found. Serum concentrations of IGF-I were also positively related to BMI (diabetic patients: $r=0.41, p<0.0005$; control subjects: $r=0.20, p<0.05)$.

Figure 3 shows the relationship between the insulin dose per $\mathrm{kg}$ body weight and serum levels of GH-BP (upper panel) and IGF-I (lower panel) in the diabetic patients as evaluated by univariate linear regression analysis. The insulin dose per $\mathrm{kg}$ body weight was positively related to serum concentrations of GH-BP $(r=0.34$; $p<0.005)$ and of IGF-I $(r=0.31 ; p<0.02)$.

No relationship could be found between serum levels of GH-BP and IGF-I, either in the diabetic patients $(r=0.18$; NS) or in the control subjects $(r=0.05$; NS $)$. 


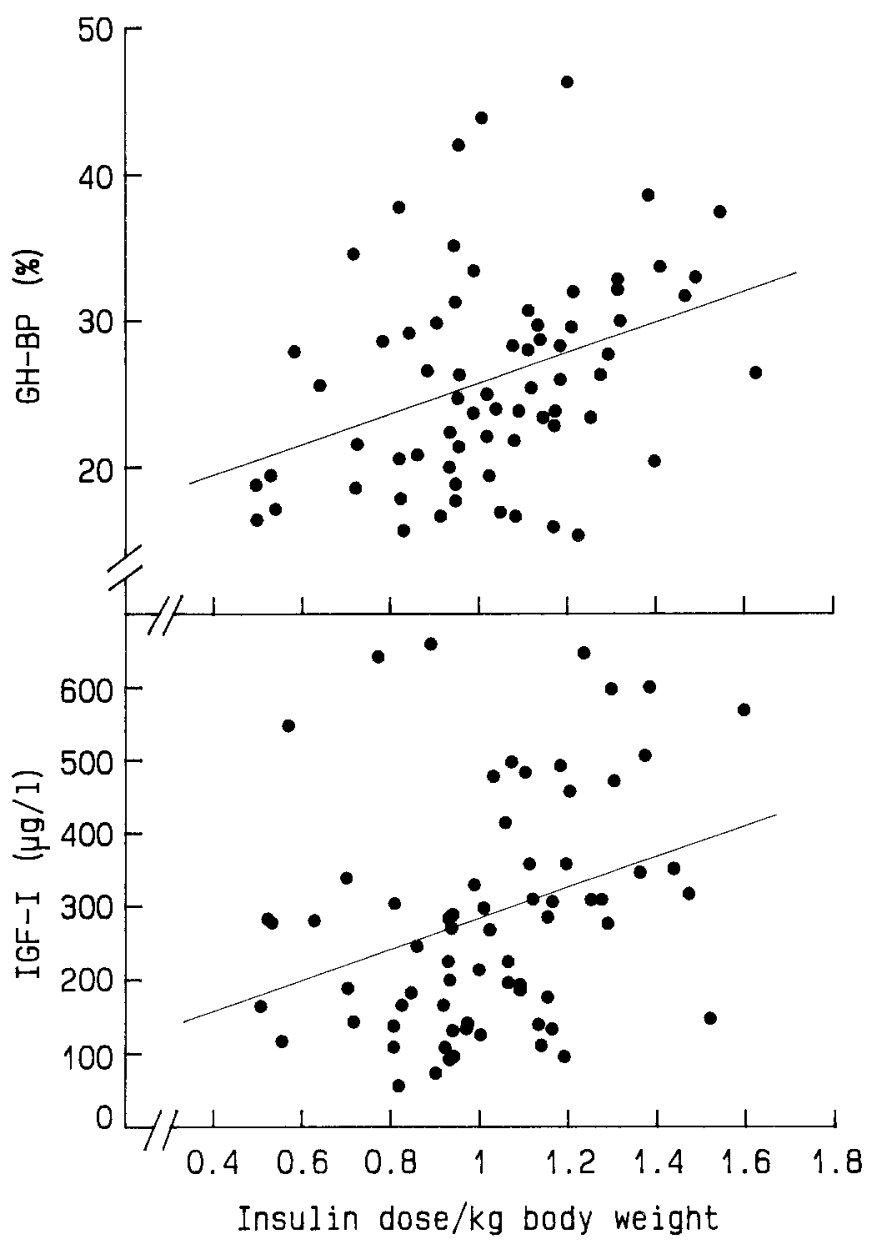

Fig.3. Relationship between insulin dose per $\mathrm{kg}$ body weight (units $/ \mathrm{kg}$ ) and serum levels of growth hormone-binding protein (GH-BP, upper panel; $r=0.34 ; p<0.005$ ) and of insulin-like growth factor I (IGF-I, lower panel; $r=0.31 ; p<0.02)$

\section{Discussion}

This study shows in a large series of children and adolescents with long-standing Type 1 diabetes that serum levels of GH-BP and IGF-I are reduced in comparison to nondiabetic control subjects. Moreover, the serum concentrations of GH-BP are influenced by BMI and insulin therapy, and those of IGF-I, by pubertal stage.

In the literature, limited information is available on serum levels of GH-BP in patients with diabetes. Mauras et al. [23] reported normal levels of GH-BP in two boys with Mauriac syndrome and in five boys with Type 1 diabetes with normal growth, aged 9.7 to 15.5 years. Menon et al. [24], in contrast, found lower serum GH-BP levels in prepubertal and pubertal children, but not in postpubertal subjects. Mercado et al. [25] reported decreased levels of plasma GH-BP in adults with Type 1 but not with Type 2 (non-insulin-dependent) diabetes. In agreement with the latter studies two-way ANOVA revealed a significant negative effect of Type 1 diabetes on serum levels of GH-BP in our diabetic patients.

Several studies have shown that the nutritional state is an important modulator of serum levels of GH-BP [20, 26-30]. We recently demonstrated a positive relationship between the ponderal index and serum levels of GH-BP in neonates [20] and between weight expressed as percentage of median weight for height age and serum GH-BP concentrations in healthy pubertal subjects [30]. In agreement with these findings, serum levels of GH-BP in the present study were positively related to BMI, in the diabetic patients and in the control subjects, a finding also reported by Mercado et al. [25]. The two regression lines were parallel with a difference in elevation of $5 \%$ of binding. The higher BMI in the diabetic patients masks their relatively lower levels of GH-BP. Indeed, ANCOVA with $\mathrm{BMI}$ as covariate confirmed a highly significant negative effect of Type 1 diabetes on serum levels of GH-BP.

As recently reported for healthy girls and boys [30], serum levels of GH-BP in diabetic children and adolescents were not influenced by pubertal stage or gender. A positive relationship was found between serum levels of GH-BP and the insulin dose per kg body weight. Although insulin dose per $\mathrm{kg}$ body weight is not an adequate reflection of circulating insulin levels, the positive relationship suggests that insulin is one of the regulators of the serum levels of GH-BP. This finding is in agreement with the data of Baxter et al. $[7,8]$ who showed that the somatogenic receptor of rat liver, to which the GH-BP is qualitatively [15] and quantitatively $[12,26,31]$ related, is regulated by insulin.

In agreement with the data from the literature [4-6], serum levels of IGF-I in diabetic patients increase during puberty, but to a lesser extent than in control subjects, especially during late puberty. The concentrations are positively related to BMI and insulin dose per kg body weight, but these effects disappear in multivariate linear regression analysis and are therefore less important than the effect of puberty. No relationship was found between serum levels of GH-BP and IGF-I, either in the diabetic patients or in the control subjects. In both groups of subjects serum concentrations of IGF-I increase during puberty without changes in serum GH-BP levels. This suggests that the increasing levels of sex steroids during puberty influence hepatic IGF-I production at a post-GH receptor level. The lower serum concentrations of GH-BP, reflecting a lower number of hepatic GH receptors, might explain the lower serum IGF-I levels in prepubertal and early pubertal diabetic patients. It is, however, unlikely that the small decrease in serum GH-BP levels in our late pubertal diabetic patients can explain the strongly suppressed serum levels of IGF-I at this stage. Post-GH receptor defects $[9,10]$ blunting the effect of sex-steroids on IGF-I production, or disturbances in the serum levels of IGF-binding proteins $[32,33]$ resulting in accelerated IGF-I clearance, probably contribute more to these lower serum levels of IGF-I. Further studies are required to elucidate the relationship between serum levels of GH-BP and IGF-I in diabetic as well as in healthy subjects.

Acknowledgements. The continuous support of Prof. E. Eggermont is gratefully acknowledged. This work was supported by grants from the Belgian "Nationaal Fonds voor Geneeskundig Wetenschappelijk Onderzoek" (3.0047.89), the Belgian Study Group for Paediatric Endocrinology, Novo-Nordisk (Denmark) and Laboratoires Serono France. 


\section{References}

1. Hayford JT, Danney MM, Hendrix JA, Thompson RG (1980) Integrated concentration of growth hormone in juvenile-onset diabetes. Diabetes 29: 391-398

2. Horner JM, Kemp SF, Hintz RL (1981) Growth hormone and somatomedin in insulin-dependent diabetes mellitus. J Clin Endocrinol Metab 53: 1148-1153

3. Edge JA, Dunger DB, Matthews DR, Gilbert JP, Smith CP (1990) Increased overnight growth hormone concentrations in diabetic compared with normal adolescents. J Clin Endocrinol Metab 71: 1356-1362

4. Blethen SL; Sargeant DT, Whitlow MG, Santiago JV (1981) Effect of pubertal stage and recent blood glucose control on plasma somatomedin Cin children with insulin-dependent diabetes mellitus. Diabetes 30: 868-872

5. Amiel SA, Sherwin RS, Hintz RL, Gertner JM, Press CM, Tamborlane WV (1984) Effect of diabetes and its control on insulinlike growth factors in the young subject with type I diabetes. Diabetes 33: 1175-1179

6. Rogers DG, Sherman LD, Gabbay KH (1991) Effect of puberty on insulin like growth factor $\mathrm{I}$ and $\mathrm{HbA}_{1}$ in type $\mathrm{I}$ diabetes. Diabetes Care 14: 1031-1035

7. Baxter RC, Turtle JR (1978) Regulation of hepatic growth hormone receptors by insulin. Biochem Biophys Res Commun 84 : 350-357

8. Baxter RC, Bryson JM, Turtle JR (1980) Somatogenic receptors of rat liver: regulation by insulin. Endocrinology 107: 1176-1181

9. Maes M, Underwood LE, Ketelslegers JM (1986) Low serum somatomedin-Cin insulin-dependent diabetes: evidence for a postreceptor mechanism. Endocrinology 118: 377-382

10. Bornfeldt KE, Arnqvist HJ, Enberg B, Mathews LS, Norstedt G (1989) Regulation of insulin-like growth factor-I and growth hormone receptor gene expression by diabetes and nutritional state in rat tissues. J Endocrinol 122: 651-656

11. Ymer SI, Herington AC (1985) Evidence for the specific binding of growth hormone to a receptor-like protein in rabbit serum. Mol Cell Endocrinol 41:153-161

12. Massa G, Mulumba N, Ketelslegers J-M, Maes M (1990) Initial characterization and sexual dimorphism of serum growth hormone-binding protein in adult rats. Endocrinology 126: 19761980

13. Baumann G, Stolar MW, Amburn K, Barsano CP, DeVries BC (1986) A specific growth hormone-binding protein in human plasma: initial characterization. J Clin Endocrinol Metab 62: 134-141

14. Herington AC, Ymer S, Stevenson J (1986) Identification and characterization of specific binding proteins for growth hormone in normal human sera. J Clin Invest 77: 1817-1823

15. Leung DW, Spencer SA, Cachianes G et al. (1987) Growth hormone receptor and serum binding protein: purification, cloning and expression. Nature 330: 537-543

16. Daughaday WH, Trivedi B, Andrews BA (1987) The ontogeny of serum GH binding protein in man: a possible indicator of hepatic GH receptor development. J Clin Endocrinol Metab 65: $1072-1074$

17. Tanner JM (1962) Growth at adolescence. 2nd edn. Blackwell Scientific Publishers, Oxford

18. Roede MJ, Van Wieringen JC (1985) Growth diagrams 1980 Netherlands third nation-wide survey. Tijdschr Soc Gezondheidsz 63 [Suppl]: 1-34
19. Rolland-Cachera MF, Sempé M, Guilloud-Bataille M, Patois E, Péquignot-Guggenbuhl F, Fautrad V (1982) Adiposity indices in children. Am J Clin Nutr 36: 178-184

20. Massa G, de Zegher F, Vanderschueren-Lodeweyckx M (1992) Serum growth hormone-binding proteins in the human foetus and infant. Pediatr Res 32: 69-72

21. Verhaeghe J, Suiker AMH, Visser WJ, Van Herck E, Van Bree R, Bouillon R (1992) The effects of systemic insulin, insulin-like growth factor-I and growth hormone on bone growth and turnover in spontaneously diabetic BB rats. J Endocrinol 134: 485492

22. Gustafson TL (1991) True epistat manual, Epistat Services, Richardson, Texas

23. Mauras N, Merimee T, Rogol AD (1991) Function of the growth hormone-insulin-like growth factor I axis in the profoundly growth-retarded diabetic child: evidence for defective target organ responsiveness in the Mauriac syndrome. Metabolism 40: 1106-1111

24. Menon RK, Arslanian S, May B, Cutfield WS, Sperling MA (1992) Diminished growth hormone-binding protein in children with insulin-dependent diabetes mellitus. J Clin Endocrinol Metab 74: 934-938

25. Mercado M, Molitch ME, Baumann G (1992) Low plasma growth hormone binding protein in IDDM. Diabetes 41: 605-609

26. Mulumba N, Massa G, Ketelslegers J-M, Maes M (1991) Ontogeny and nutritional regulation of the serum growth hormonebinding protein in the rat. Acta Endocrinol (Copenh) 125: 409 415

27. Hochberg Z, Hertz P, Colin V et al. (1992) The distal axis of growth hormone $(\mathrm{GH})$ in nutritional disorders: $\mathrm{GH}$-binding protein, insulin-like growth factor-I (IGF-I), and IGF-I receptors in obesity and anorexia nervosa. Metabolism 41: 106-112

28. Silbergeld A, Lazar L, Erster B, Keret R, Tepper R, Laron Z (1989) Serum growth hormone binding protein activity in healthy neonates, children and young adults: correlation with age, height and weight. Clin Endocrinol (Oxf) 31:295-303

29. Holl R, Snehotta R, Siegler B, Scherbaum W, Heinze E (1991) Binding protein for human growth hormone: effects of age and weight. Horm Res 35: 190-197

30. Massa G, Bouillon R, Vanderschueren-Lodeweyckx M (1992) Serum levels of growth hormone-binding protein and insulinlike growth factor I during puberty. Clin Endocrinol 37: 175-180

31. Ambler GR, Breier BH, Surus A et al. (1992) The interrelationship between and the regulation of hepatic growth hormone receptors and circulating GH binding protein in the pig. Acta Endocrinol (Copenh) 126: 155-161

32. Arner P, Sjöberg S, Gjötterberg M, Skottner A (1989) Circulating insulin-like growth factor I in type 1 (insulin-dependent) diabetic patients with retinopathy. Diabetologia 32: 753-758

33. Batch JA, Baxter RC, Werther G (1991) Abnormal regulation of insulin-like growth factor binding proteins in adolescents with insulin-dependent diabetes. J Clin Endocrinol Metab 73: 964-968

Received: 27 July 1992

and in revised form: 22 October 1992

Dr. G. Massa

Department of Paediatrics

University Hospital Gasthuisberg

Herestraat 49

B-3000 Leuven

Belgium 